DOI: 10.33766/2524-0323.91.89-101

УДК 342.951:351.82

Н. В. Камінська,

доктор юридичних наук, професор, професор кафедри конституційного права

та прав людини

Національної академії внутрішніх справ

(м. Київ, Україна)

e-mail:na-pro@ukr.net

iDhttps://orcid.org/0000-0002-7727-4056

М. О. Акімов,

кандидат юридичних наук, доцент, доцент кафедри кримінального права

Національної академії внутрішніх справ

(м. Київ, Україна)

e-mail:mike_hedgehog@ukr.net

iDhttps:/ / orcid.org/0000-00012-7715-0259

\title{
ВІДПОВІДАЛЬНІСТЬ ДЕРЖАВИ ЗА ЗНИЩЕННЯ ЦИВІЛЬНИХ ПОВІТРЯНИХ СУДЕН: ОСОБЛИВОСТІ МІЖНАРОДНО-ПРАВОВОГО ТА НАЦІОНАЛЬНОГО РЕГУЛЮВАННЯ
}

У статті здійснено аналіз існуючих міжнародно-правових та деяких національних джерел як підстав настання відповідальності держави за знищення цивільних повітряних суден поряд 3 іншими неправомірними діяннями у сфері міжнародної цивільної авіації. Це зумовило вивчення стану міжнародно-правового та національного правового регулювання інституту відповідальності держави. Розкрито особливості притягнення до відповідальності держав як основних суб'єктів повітряного права, на відміну від фізичних та юридичних осіб, міжнародних організацій, інших суб'єктів.

Хоча знищення та пошкодження цивільного повітряного судна в польоті суперечить принципу безпеки цивільної авіації, закріпленому Чиказькою конвенцією та вимогам утримуватися від застосування зброї до цивільного повітряного судна в польоті, встановлених Протоколом щодо змін Конвенції про міжнародну цивільну авіацію 1984 р. (Монреальський протокол), такі акти набули загрозливого поширення. У цілому міжнародно-правова відповідальність держави за знищення цивільного повітряного судна та, зокрема, порядок примусового виконання нею відповідних зобов'язань у частині відшкодування збитків залишаються недостатньо врегульованими, грунтуються здебільшого на звичаєвих положеннях, а відтак, потребують подальшої міжнародної і національної правотворчої діяльності.

Ключові слова: відповідальність держави, міжнародно-правове регулювання, законодавство, знищення цивільних повітряних суден, незастосування зброї, цивільна авіація, міжнародні організації.

Постановка проблеми. Незважаючи на потреби розвитку цивільної авіації, національних, транскордонних і міжнародних транспортних систем, важливим є привернення уваги держав і міжнародних організацій, наукової спільноти і практичних працівників у даній сфері до проблематики притягнення до відповідальності за діяння в міжнародному повітряному просторі,

(C) Камінська Н. В.,

Акімов М. О., 2020 
а також забезпечення безпеки повітряних польотів. Це підтверджують неодноразові факти порушень останньої, так само як і масовість та складність міжнародних повітряних перевезень, збиття літака рейсу МН-17 Малайзійських авіаліній 2014 року, знищення українського літака Boeing-737 рейсу PS-752 авіакомпанії «Міжнародні авіалінії України» на території Ісламської Республіки Іран і т. ін.

Як реакція на такі протиправні діяння, за участю керівних органів ООН світовою спільнотою було прийнято ряд правових документів, так само і двосторонніх угод, звернень та інших актів уповноважених вищих органів держав, створено спільні слідчі групи для координащії міжнародного кримінального розслідування, щоб ті, хто вчинив ці злочини, постали перед правосуддям. Водночас процес притягнення їх до відповідальності є досить тривалим, складним і таким, що потребує грунтовного вивчення.

Аналіз останніх досліджень і публікацій. Проблематика відповідальності в міжнародному повітряному праві не часто була предметом окремих наукових розвідок, проте їі теоретичні основи розкриваються такими ученими, як: М. Баймуратов, І. Білас, М. Буроменський, В. Василенко, О. Григоров, С. Демпсі, В. Денисов, О. Задорожній, А. Кулько, І. Лукашук, Ю. Пірадов, А. Пелле, О. Маловацький, О. Мережко, Р. Петров, Н. Пронюк, К. Смирнова, М. Шоу, О. Шпакович та ін. На наш погляд, важливо, щоб не лише юристи-міжнародники приділяли увагу згаданим питанням, а й представники різних галузей сучасної вітчизняної юридичної науки.

Формулювання цілей. 3 огляду на це, мета статті полягає в здійсненні аналізу існуючих міжнародно-правових та деяких національних джерел як підстав настання відповідальності держави за знищення цивільних повітряних суден поряд з іншими неправомірними діяннями у сфері міжнародної цивільної авіації. Це зумовлює вирішення низки завдань, зокрема вивчення стану міжнародно-правового та національного правового регулювання інституту відповідальності держави в міжнародному праві, правовій системі України. Також важливим є розкриття особливостей притягнення до відповідальності держав як основних суб'єктів повітряного права, на відміну від фізичних та юридичних осіб, міжнародних організацій, інших суб'єктів.

Виклад основного матеріалу. 3 часу першого польоту братів Райт у 1903 р. до започаткування першої регулярної пасажирської авіалінії в штаті Флорида (США) минуло рівно десять років. Згодом було розроблено й прийнято одразу після Першої світової війни Паризьку конвенщію 1919 р., яка дала поштовх для активного розвитку цивільної авіації, становлення майбутнього міжнародного повітряного права. У ній з-поміж іншого закріплено: абсолютний суверенітет держави щодо повітряного простору над іï територією (суходолом та територіальними водами), включаючи право заборонити вліт до нього (політ крізь нього); рівність можливостей використання повітряного простору власними та іноземними літальними апаратами тощо [1] .

Як відомо, Паризька конвенція 1919 р. про повітряну навігацію стала першою міжнародною угодою в історії, де закріплено основні правові стандарти діяльності цивільної авіації. Водночас у цьому документі передбачено запровадження спеціального міжнародного органу, а саме Міжнародної комісії з повітряних перевезень (МКПIП), до компетенщії якої віднесено значні функції у сфері міжнародно-правового співробітнищтва держав-сторін конвенщії. Одночасно, згідно з Ібероамерикан- 
ською (Мадридською) конвенцією 1926 р., передбачено створення Ібероамериканської аеронавігаційної комісії. За іншим регіональним міжнародним договором - Панамериканською (Гаванською) конвенцією 1928 р. про комерційну авіацію - функції інституційного органу співпраці держав-учасниць були покладені на Панамериканський союз, створений у межах домовленостей США та держав Латинської Америки [2].

Попри це, спосіб та межі, порядок застосування заходів примусу для забезпечення державного суверенітету щодо власного повітряного простору чітко не були визначені. Можна припустити, у тому числі й через це, уже невдовзі цивільні повітряні судна стали об'єктами ворожих дій з боку різних держав. Перше знищення пасажирського літака під час воєнних дій сталося вже через півтора десятиліття після набуття чинності Паризької конвенщії. До початку та в роки Другої світової війни найбілыш трагічними подібними інцидентами стали: знищення літака Douglas DC2 авіакомпанії Pan Amerikan 24 серпня 1938 р. поблизу Гонконгу японськими літаками (загинуло 15 осіб); літака Junkers Ju 52 авіакомпанії Aero O/Y 14 червня 1940 p. поблизу Таллінна радянськими літаками (загинуло 9 осіб); гідролітака Short Empire авіакомпанії Qantas 30 січня 1942 р. біля узбережжя Західного Тимору (загинуло 13 осіб) та літака Douglas DC-3 авіакомпанії KNILM 3 березня 1942 р. поблизу узбережжя Австралії (загинуло 4 особи) японськими літаками; літаків Douglas DC-3 авіакомпанії ВОАС 1 червня 1943 р. над Біскайською затокою (загинуло 17 осіб) та авіакомпанії АВ Aerotransport 22 жовтня 1943 р. біля узбережжя Швеції (загинуло 13 осіб) німецькими літаками [3].

У роки «холодної війни» та під час численних локальних конфліктів ворогуючі сторони подекуди сприймали будь-яку появу повітряного судна в неочікуваному місці не як відхилення від курсу через помилку екіпажу, технічну несправність чи погодні умови, а як ворожий акт (ведення розвідки, спроба бомбардування тощо). Траплялись і трагічні випадковості - помилка екіпажів ВПС / розрахунків сил та засобів протиповітряної оборони (ПО), порушення правил повітряних польотів чи пуску ракет та ін. Звісно, далеко не завжди можливо було встановити справжні причини катастроф; а держави, причетні до них, не поспішали визнавати це, і навпаки, заперечували участь або протиправність власних діянь.

Наприклад, жертвами авіації та ППО різних держав у 50-ті - 70-ті роки XX ст. стали пасажирські літаки: Douglas DC-4 авіакомпаніï Cathay Pacific Airways (збитий китайським винищувачем 23 липня 1954 р. біля острова Хайнань, загинуло 10 осіб); Lockheed L-149 Constellation авіакомпаніï El Al (збитий болгарськими винищувачами 27 липня 1955 р. поблизу болгарсько-грецького кордону, загинуло 58 осіб); Ту-104 авіакомпанії «Аерофлот» (збитий зенітною ракетою 30 червня 1962 р. біля Красноярська, загинуло 84 особи); Boeing - 727 авіакомпанії Libyan Arab Airlines (збитий ізраїльськими винищувачами 21 лютого 1973 р. над Синайським півостровом, загинуло 108 осіб); Воеing - 707 авіакомпанії Korean Airlines (збитий радянськими винищувачами 20 квітня 1978 р. біля Мурманська, загинуло 2 особи); два Vickers Viscount авіакомпанії Air Rhodesia (збиті переносними зенітними ракетами Народно-Революційної Армії Зімбабве 3 вересня 1978 р. над Родезією та 12 лютого 1979 р. біля зімбабвійсько-замбійського ко- 
рдону відповідно, загинуло 48 та 59 осіб). Найбілыше людських життів (269) забрала загибель літака Boeing - 747 авіакомпаніï Korean Airlines, збитого радянським винищувачем 1 вересня 1983 р. поблизу острова Монерон у Японському морі [3-4].

Безумовно, кожна подібна трагедія викликала широкий резонанс, призводила до всесвітнього розголосу, гучних звинувачень та (іноді) до визнання конкретних фактів і виплати компенсащій. Однак, підтверджуючи знищення певних цивільних повітряних суден, держави переважно не визнавали такі дії порушенням міжнародного права. Справді, обов' язок держави нести відповідальність за вчинення неправомірних актів $є$ однією із загальновизнаних засад міжнародного права, наріжним каменем його сучасної доктрини.

Слід зазначити, що основні міжнародно-правові акти в даній сфері регламентують загалом відповідальність фізичних осіб. Ідеться про Чиказьку конвенщію про міжнародну цивільну авіацію 1944 р., Римську конвенцію про шкоду, завдану іноземним повітряним судном третім особам на поверхні 1952 р., Токійську конвенщію про злочини й деякі інші дії на борті повітряного судна 1963 р., Гаазьку конвенщію про боротьбу із незаконним захопленням повітряних суден 1970 р., Монреальську конвенщію про боротьбу із незаконними актами, спрямованими проти безпеки цивільної авіації 1971 р., Монреальську конвенцію про уніфікацію деяких правил міжнародних повітряних перевезень 1999 р. та ін. Натомість знищення державою цивільного повітряного судна залишалась неврегульованою - подібні дії взагалі не визнавались посяганням на безпеку цивільної авіації, хоча фактично й були такими.

Безумовно, держава зобов'язана забезпечити безпеку цивільної авіації - як у частині запобігання (припинення) актів незаконного втручання в регламентований порядок здійснення польотів, так і в частині технічної безпеки організації та проведення останніх (причому, незалежно від наявності / відсутності стану війни / надзвичайних ситуацій). Цей принцип закріплений Монреальським протоколом 1984 р., на підставі якого Чиказька конвенція 1944 р. була доповнена статтею 3bis, що зобов'язує всі держави-учаснищі утриматись від застосування зброї протицивільнихповітряних суден (за винятком реалізащії передбаченого ст. 51 Статуту ООН права на самооборону) [5].

На наш погляд, потребують розкриття підстави міжнародно-правової відповідальності держав за знищення цивільного повітряного судна, з огляду на існуючі міжнародно-правові акти. У даному контексті модна виокремити дві підстави - юридичну та фактичну. До першої слід віднести сукупність зобов' язань, узятих на себе державою у зв' язку з приєднанням у той чи інший спосіб до певних міжнародноправових актів, порушення яких (невиконання, неналежне виконання) утворює міжнародно-протиправне діяння. Другу ж становить безпосередньо діяння (дія чи бездіяльність), вчинене державою (ії органом, установою, представником) або від імені держави на порушення взятих на себе міжнародно-правових зобов' язань.

Відповідно до положень ст. 2 Статуту, ООН зобов' язує держави утримуватися від загрози / використання сили в міжнародних відносинах. Крім цього, згідно з резолюцією Генеральної Асамблеї ООН № 2625 від 24 жовтня 1970 р., держави зобов' язані сприяти дотриманню прав людини та основоположних свобод, закріплених Загальною декларацією прав людини та Міжнародним пактом про громадянські та політичні права, де право на життя та безпеку людини є основоположним 
правом, що підлягає захисту. Наведені міжнародно-правові акти створюють юридичну підставу міжнародно-правової відповідальності держави за знищення цивільного повітряного судна.

Свою чергою, фактичну ж підставу такої відповідальності складають: неправомірне діяння (дія або бездіяльність), вчинене на порушення взятих на себе державою міжнародно-правових зобов' язань; належність конкретної особи (групи осіб, органу, установи), якою (якими) вчинено зазначене діяння, до певної держави в тій чи іншій формі (громадянство / підданство, перебування на службі / під контролем держави, згода / сприяння / пособництво держави та ін.).

Слід зауважити, що в разі вчинення діяння в порядку реалізації права на держави на самооборону, а так само в умовах форс-мажору, потерпання від лиха або за згоди іншої держави на його вчинення, воно вважається вчиненим за умов, що виключають його міжнародну протиправність. Водночас це не означає виключення відповідальності як такої, оскільки остання передбачає відшкодування завданих збитків та реалізацію порушених зобов'язань. Інакше кажучи, якщо винна фізична особа повинна нести кримінальну відповідальність у разі, коли вчинене нею діяння є злочином, то держава, від імені якої діяла ця особа, нестиме міжнародно-правову відповідальність (насамперед, ідеться про відшкодування завданих збитків, відновлення порушених прав, продовження реалізащії взятих на себе зобов' язань).

Вимога про відшкодування заподіяної шкоди - одночасно і право потерпілої сторони (держави, де було зареєстровано знищене повітряне судно, громадяни якої постраждали, тощо), і ії обов' язок (по-перше, відсутність подібного звернення можна тлумачити як мовчазну згоду із неправомірним актом, що, за міжнародним правом, виключатиме будь-яке відшкодування шкоди; по-друге, кожна держава повинна всіма дипломатичними засобами захищати власних громадян за кордоном). Повноваження компетентного органу для вирішення суперечки, що виникла, та врегулювання питання відшкодування завданої шкоди виконує зазвичай третя сторона міжнародна організація / установа (арбітраж, створений відповідно до умов, передбачених Чиказькою конвенщією 1944 р., Рада Міжнародної організації цивільної авіащіï, Свропейський суд із прав людини, Міжнародний Суд ООН).

У разі невиконання державою своїх зобов' язань потерпіла сторона має право вжити ті примусові заходи, що їх вона вважатиме найбілыш прийнятними в даній ситуації. Це можуть бути: контрзаходи (дії постраждалої держави у відповідь, що порушують міжнародно-правові зобов'язання, проте, 3 огляду на їх обумовленість, протиправною поведінкою держави-порушника, тимчасовість та пропорційність не вважаються неправомірними); санкції (дії у відповідь постраждалої держави, інших держав та міжнародних організацій, у тому числі застосування сили проти державипорушника, що виконуються згідно з рішенням Ради Безпеки ООН та на підставі Статуту ООН, або відповідно до рішення Міжнародного Суду ООН, або за рішенням Міжнародної організації цивільної авіації) [4; 6-8].

Висловлюються припущення, що відповідальність держави за неправомірні акти досі грунтується на звичаєвому міжнародному праві, оскільки схвалений резолюцією Генеральної Асамблеї ООН № 56/589 від 12 грудня 2001 р. проєкт документу «Відповідальність держав за міжнародно-протиправні діяння» так і не був прийнятий). Як зауважує О. Маловацький, відповідальність держави за неправомірні акти - знищення чи 
пошкодження цивільного повітряного судна в польоті, нормами міжнародного договірного права не врегульована. Навіть білыше, термінологічний апарат міжнародного повітряного права не визначає такі акти незаконним втручанням у безпеку цивільної авіащії, а характеризує їх як акти, що суперечать «гуманності» та «повазі до елементарних норм міжнародного спілкування», та називає державним піратством, саботажем або актами тероризму [9-10].

Не оминули випадки знищення державами цивільних повітряних суден й Україну. У 2014 р. військовими засобами було знищено цивільне повітряне судно Малайзійських авіаліній, рейс МН-17, над територією України. Проблема відповідальності держави за знищення чи пошкодження цивільного повітряного судна в польоті набуває для України особливої актуальності, оскільки країна потерпає від агресивних дій Російської Федерації, а інщидент з рейсом МН-17 є лише проявом таких дій.

Нагадаємо, що на вимоги США, Франщії, Великої Британії та Ірландії, РБ ООН ухвалила Резолюцію 731, якою визнала, що участь Лівії в актах міжнародного тероризму загрожує миру та безпеці, а тому Лівія зобов'язана дієво відмежуватися від указаних актів та видати осіб, винних у вчиненні вказаного акту. Лівія заперечила такі вимоги та звернулася до Міжнародного Суду ООН, однак суд визнав, що зобов'язання, які випливають із Резолюцій РБ ООН, домінують над зобов'язаннями, які виходять з інших міжнародних договорів. Водночас, в аналогічній справі про збиття рейсу МН-17 механізм РБ ООН себе не виправдав через позищію Російської Федеращії: у резолющії 2166 (2014) знищення рейсу МН-17 не було визнано актом, який загрожує миру та безпеці, що потребує подалышого удосконалення. Даний документ вимагає, щоб особи, відповідальні за збиття літака рейсу МН-17 Малайзійських авіаліній були притягнуті до відповідальності і щоб усі держави повністю співпрацювали й доклали максимальних зусиль для встановлення відповідальності [11-12].

Прикметно, що було створено Спільну Слідчу Групу (ССГ) для координації міжнародного кримінального розслідування, щоби ті, хто вчинив ці злочини, постали перед правосуддям. До їі складу включено представників Австралії, Королівства Бельгії, Малайзії, Королівства Нідерландів та України. Держави, які беруть участь у ССГ, визначили, що в інтересах належного відправлення правосуддя буде зосередити переслідування та засудження за злочини, пов'язані зі збиттям літака рейсу МН-17 Малайзійських авіаліній, у Королівстві Нідерландів. Судові органи Держав, які беруть участь у ССГ, погодилися консультуватися одна з одною щодо переслідування чи відповідних заходів, пов'язаних зі збиттям літака рейсу МН-17 Малайзійських авіаліній. Цепідтверджується Угодою між Україною та Королівством Нідерландів про міжнародне правове співробітнищтво щодо злочинів, пов'язаних зі збиттям літака рейсу МН-17 Малайзійських авіаліній 17 липня 2014 р. (ратифіковано із заявами Законом України № 2506-VIII від 12.07.2018.p) [13], і на підставі Угоди про співробітництво між Україною та Свропейською організацією з питань юстищії, укладеної 2016 р., та Угодою між Україною та Європейським поліцейським офісом про оперативне та стратегічне співробітнищтво, укладеної 2016 р.; Свропейської конвенщії про передачу провадження в кримінальних справах, 1972 p.

Так названою Угодою між Україною та Королівством Нідерландів 2014 р. регламентовано будь-який злочин, пов'язаний зі збиттям літака рейсу МН-17 і питання, що сто- 
суються або виникають у зв'язку із переслідуванням та засудженням у Королівстві Нідерландів за злочини, пов'язані зі збиттям в Україні літака рейсу МН-17 Малайзійських авіаліній 17 липня 2014 року. Сторони надають одна одній найширші заходи співробітнищтва стосовно переслідування та засудження за ці злочини і виконання будь-якого покарання, призначеного за ці злочини.

Свою чергою, нормативно-правова база України, що регулює діяльність цивільної авіації України, містить близько тисячі нормативно-правових актів. Основний із них це Повітряний кодекс України. Також діє значна кількість підзаконних нормативноправових актів України, з-поміж яких слід виокремити Положення про використання повітряного простору України, затверджене постановою КМУ 2017 р. Положення визначає організацію використання повітряного простору України в інтересах нащіональної безпеки та економіки з метою задоволення потреб користувачів повітряного простору, забезпечення безпеки використання повітряного простору. Тут зазначено, що управління використанням (менеджмент) повітряного простору України здійснюється за принципами гнучкого використання повітряного простору на стратегічному, передтактичному і тактичному рівні. Це покладається Державіаслужбою та Міноборони, органами об'єднаної цивільно-військової системи організації повітряного руху [15]. Зауважимо, що фактично питання відповідальності держави в даній сфері не регламентовано в Положенні.

Традищійно в національному законодавстві правову відповідальність пов' язують із застосуванням заходів державного примусу, розглядають ії як передбачену санкціями правових норм реакцію на правопорушення, реалізацію, застосування і здійснення санкцій. Зокрема, адміністративна відповідальність в Україні та процедура притягнення до адміністративної відповідальності в галузі цивільної авіації грунтуються на конституційних принципах і правових презумпщіях, які зумовлені виконанням та дією саме принщипу верховенства права в Україні. Конституція України має найвищу юридичну силу, закони та інші нормативно-правові акти приймаються на основі Конституції України і повинні відповідати йй (ч. 2 ст. 8). До принципів адміністративної відповідальності в галузі цивільної авіації належать такі: верховенство права, законності, доцільності, обгрунтованості, невідворотності, своєчасності, справедливості, гуманізму, індивідуалізації покарання, відповідності провини та покарання тощо [22-23].

Видається доцільним, що питання відповідальності держави за знищення цивільних повітряних суден, поряд з іншими неправомірними діяннями у сфері міжнародної цивільної авіації, повинні стати предметом розгяду і в інших галузях права і законодавства, включаючи кримінальне. Важливим напрямом у вдосканаленні питання відповідальності держави за знищення цивільних повітряних суден є участь громадськості в цьому процесі, яка має цілий комплекст відповідних правових інструмнтів, що передбачено на рівні міжнародних актів [24] та актів національного законодавства [25]. Саме завдяки приверненню уваги громадськості до знещення цивільного повітряного судна це питання не замовчується, а перебуває у фокусі обговорюваних у суспільстві.

На підставі аналізу правового регулювання державної політики безпеки польотів повітряних суден цивільної авіащії дослідники визначають ії систему, яка спрямовується в першу чергу на забезпечення безпеки польотів повітряних суден цивільної авіації шляхом впровадження системи управління безпекою польотів усіма суб'єктами 
авіаційної діяльності, згідно з вимогами Міжнародної організації цивільної авіації. Погоджуємось, що серед основних напрямків удосконалення державної політики в цій сфері є удосконалення системи державного управління цивільною авіацією шляхом:

- корегування державної політики з питань забезпечення безпеки польотів;

- впровадження кожним суб'єктом авіаційної діяльності прийнятних рівнів безпеки польотів;

- управління ризиками в галузі цивільної авіаціі;

- впровадження європейських стандартів щодо виконання та забезпечення польотів [22-23, 26].

Також доречно доповнити наведений перелік заходами, спрямованими на забезпечення відповідальності держави за знищення цивільних повітряних суден. Слушними є пропозищії про посилення відповідальності в даній сфері шляхом внесення відповідних змін до КУпАП та Кримінального кодексу України [6; 10-11; 22-23, 26].

Міжнародні зобов'язання України, зокрема, підписання в 2001 році Україною Кіпрських домовленостей, а також стратегічний курс України на інтеграцію до Свропейського Союзу, передбачають приведення законодавства України у сфері забезпечення безпеки цивільної авіації взагалі і їі галузевого регулювання до світових стандартів. У процесі адаптації національної законодавчої бази України до міжнародно-правових стандартів, європейського acquis communautaire реалізовано проєкт технічної допомоги «Приєднання до/та імплементація Україною міжнародних угод та конвенщій у галузі транспорту» (за утастю СС) ухвалено «План заходів щодо виконання загальнодержавної програми адаптації законодавства України до законодавства Свропейського Союзу». Тобто мають бути гармонізовані законодавчо та приведені у відповідність до європейських стандартів спільні європейські правила цивільної авіації (гармонізація правил та процедур у цивільній авіації, процедури ліцензування; управління рухом, спільні заходи щодо розвитку системи нового покоління управління європейським повітряним рухом (SESAR), нормативна база для створення єдиного європейського неба; безпека повітряних польотів); стандарти техніки безпеки та експлуатації (повідомлення про інциденти у цивільній авіації); авіащійна техніка безпеки (повітряні судна третіх країн, які використовують аеропорти СС, аварії та інщиденти в цивільній авіації і т. інш.).

Висновки. Проведений аналіз міжнародно-правового та національного регулювання відповідальності держави за знищення цивільних повітряних суден засвідчив певні здобутки та проблеми. Хоча знищення та пошкодження цивільного повітряного судна в польоті суперечить принципу безпеки цивільної авіації, закріпленому Чиказькою конвенщією та вимогам утримуватися від застосування зброї до цивільного повітряного судна в польоті, встановлених Протоколом щодо змін Конвенції про міжнародну цивільну авіацію 1984 р. (Монреальський протокол), такі акти набули загрозливого поширення.

У цілому міжнародно-правова відповідальність держави за знищення цивільного повітряного судна та, зокрема, порядок примусового виконання нею відповідних зобов' язань у частині відшкодування збитків залишаються недостатньо врегульованими, грунтуються здебілышого на звичаєвих положеннях, а відтак, потребують подальшої міжнародної і національної правотворчої діяльності. До питань підвищення відповідальності держав та інших суб'єктів, удосконалення системи без- 
пеки цивільної авіації слід привертати увагу не лише після виникнення потенційних загроз і жахливих наслідків, а і з метою попередження, а у випадку їх настання оперативного розслідування таких інщидентів, притягнення винних до відповідальності і відшкодування заподіяних збитків.

\section{Використані джерела:}

1. Convention Relating to the Regulation of Aerial Navigation. Signed At Paris, October 13, 1919. League of Nations Treaty Series. 1922. No. 297. P. 173.

2. Григоров О. М. Перші міжнародні інституції у сфері цивільної авіації. URL:http:// pravoisuspilstvo.org.ua/archive/2020/2_2020/part_3/34.pdf.

3. Акімов М. О. До питання про історію міжнародно-правового регулювання незастосування державою зброї до цивільного повітряного судна. Держава і право в умовах глобалізаиіі: реалії та перспективи: матер. міжнар. наук.-практ. конф. (м. Дніпро, 31 січня - 1 лютого 2020 р.). Дн.: Правовий світ, 2020. С. 97-100.

4. Акімов М. О. Міжнародно-правова регламентація відповідальності держави за знищення цивільного повітряного судна. Правові засади суверенного розвитку Украйни в сучасних умоbax: матер. міжнар. наук.-практ. конф. (м. Київ, 31 січня - 1 лютого 2020 р.) К., 2020. С. 98-102.

5. Статут ООН 1945 р. Міжнародне право в документах / М. В. Буроменський (уклад.), Харків, 2003. 376 с.

6. Козачок І. Я. Правові засади відповідальності перевізника за національним та міжнародним законодавством. Юридичний Вісник. 2013, № 1(26). С. 24-28.

7. Пронюк Н. В. Сучасне міжнародне право: навч. посіб. Київ: КНТ, 2010. 280 с.

8. Авиационная безопасность: международные конвенщии и Приложение 17 / [сост.: А. Г. Корченко, С. В. Корпенко, Е. В. Пацира]. К.: НАУ, 2004. 166 с.

9. Маловацький О. Відповідальність держави за знищення цивільного повітряного судна в результаті застосування зброї. Evropsky politicky a pravni diskurz. 2018. Vol. 5, Iss. 2. C. 25-36. URL: http://nbuv.gov.ua/UJRN/evrpol_2018_5_2_5.

10. Маловацький О. В. Міжнародно-правова відповідальність держави за знищення цивільного повітряного судна. автореф. дисерт. на здобуття наук. ступеня канд. юрид. наук за спеціальністю 12.00.11 - міжнародне право/ Інститут законодавства Верховної Ради України. Київ, 2019. 21 с.

11. Григоров О. М. Міжнародно-правові засади регулювання відносин у сфері цивільної авіації: становлення та розвиток: монографія. Київ, 2020. 440 с.

12. Резолюція ГА ООН № 56/589 (2001); Резолюція 71/133 ГА ООН (2016); резолюція 2166 РБООН (2014) URL:www.un.org.

13. Угода між Україною та Королівством Нідерландів про міжнародне правове співробітництво щодо злочинів, пов'язаних зі збиттям літака рейсу МН17 Малайзійських авіаліній 17 липня 2014 р./ Угоду ратифіковано із заявами Законом № 2506-VIII від 12.07.2018. URL:https://zakon.rada.gov.ua/laws/show/528_002-17\#Text.

14. Повітряний кодекс України/ редакція від 07.08.2020. URL: https://zakon.rada. gov.ua/laws/show/3393-17\#Text.

15. Про затвердження Положення про використання повітряного простору України: постанова КМУ від 6 грудня 2017 р. № 954. URL:https:/ /zakon.rada.gov.ua/laws/show/9542017-\%D0\%BF\#Text.

16. Кодекс України про адміністративні правопорушення.URL:https:/ / zakon. rada.gov.ua/laws/show/80731-10\#Text. 
17. Чиказька конвенщія про міжнародну цивільну авіацію 1944 p. URL:https:// zakon.rada.gov.ua; ICAO (EUR/NAT). International Civil Aviation Organization. URL:https:// www.icao.int/.

18. Convenio iberoamericano denavegación aérea. Poder Ejecutivo Federal. Estados Unidos Mexicanos. México. 1929. 42 p.

19. Монреальська конвенція про уніфікацію деяких правилміжнародних повітряних перевезень 1999 р., Конвенщія про шкоду завдану іноземним повітряним судном третім особам на поверхні 1952 р., Монреальська конвенція про боротьбу з незаконними актами, спрямованими проти безпекицивільної авіації1971 p. URL:https:/ zakon.rada.gov.ua/.

20. Войціховський А. В. Міжнародне право: підручник. Харків, 2020. 544 с.

21. Kaminska N., Siokh K., Demidenko V. Trends in the Development of International Legal Personality and Subjects of International Law: Theoretical Analysis. OPCION. Universidad del Zulia. 2018. Vol. 34 , Num. 87-2. P. 507-520.

22. Бичков А. С. Адміністративна відповідальність за порушення правил безпеки польотів: автореф. на здобуття наук. ступеня канд. юрид. наук: спец. 12.00.07 - адміністративне право та процес; фінансове право; інформаційне право. Київ, 2010. 20 с.

23. Развадовський В. Й. Місце законодавства, яке містить норми адміністративного права, у транспортному законодавстві. Наме право. 2004. № 2. С. 38-45.

24. Нестерович В. Ф. Міжнародно-правове закріплення інституту лобіювання на прикладі Ради Свропи та модельного законотворення СНД. Міжнародний науковий журнал «Влада. Людина. Закон». 2010. № 9. С. 33-41.

25. Нестерович В. Ф. Конституційно-правові засади здійснення впливу громадськості на прийняття нормативно-правових актів в Україні. Бюлетень Міністерства юстиції України. 2011. № 3. C. 32-41.

26. Пасічук А. М. Адаптація національного авіаційного законодавства до норм та принципів EC. URL:https://nau.edu.ua/site/variables/docs/docsmenu/stud nauka/polit2013/ tezy/ $522-561 \% 20 \% \mathrm{D} 0 \% \mathrm{BF} \% \mathrm{D} 1 \% 80 \% \mathrm{D} 0 \% \mathrm{~B} 0 \% \mathrm{D} 0 \% \mathrm{~B} 2 \% \mathrm{D} 0 \% \mathrm{BE}$. pdf.

\section{References:}

1. Convention Relating to the Regulation of Aerial Navigation (1922). League of Nations Treaty Series. No. 297, 173. [in English].

2. Hryhorov, O. M. Pershi mizhnarodni instytutsii u sferi tsyvilnoi aviatsii. N. p. URL:http:// pravoisuspilstvo.org.ua/archive/2020/2_2020/part_3/34.pdf. [in Ukrainian].

3. Akimov, M. O. (2020) Do pytannia pro istoriiu mizhnarodno-pravovoho rehuliuvannia nezastosuvannia derzhavoiu zbroi do tsyvilnoho povitrianoho sudna. Derzhava i pravo v umovakh hlobalizatsii: realii ta perspektyoy: mater. mizhnar. nauk.-prakt. konf. (m. Dnipro, 31 sichnia - 1 liutoho 2020 r.).-State and law in the context of globalization: realities and prospects: mater. international scientific-practical conf. (Dnipro, January 31 - February 1, 2020). Dnipro: Pravovyi svit, 97-100. [in Ukrainian].

4. Akimov, M. O. (2020) Mizhnarodno-pravova rehlamentatsiia vidpovidalnosti derzhavy za znyshchennia tsyvilnoho povitrianoho sudna. Pravovi zasady suverennoho rozvytku Ukrainy $v$ suchasnykh umovakh: mater. mizhnar. nauk.-prakt. konf. (m. Kyiv, 31 sichnia - 1 liutoho 2020 r.)- State and law in the context of globalization: realities and prospects: Mater. international scientific-practical conf. (Dnipro, January 31 - February 1, 2020) Kyiv, 98-102. [in Ukrainian].

5. Statut OON 1945 r. Mizhnarodne pravo v dokumentakh. (2003) M. V. Buromenskyi (Ed.). Kharkiv. [in English].

6. Kozachok, I. Ya. (2013) Pravovi zasady vidpovidalnosti pereviznyka za natsionalnym ta mizhnarodnym zakonodavstvom. Yurydychnyi visnyk-Legal Bulletin №1(26), 24-28. [in Ukrainian]. 
7. Proniuk, N. V. (2010) Suchasne mizhnarodne pravo: navch. posib. Kyiv: KNT. [in Ukrainian].

8. Aviacionnaya bezopasnost: mezhdunarodnye konvencii i Prilozhenie 17/ (2004) A. G. Korchenko, S. V. Korpenko, E. V. Pacira (Eds.). Kyiv: NAU. [in Russian].

9. Malovatskyi, O. (2018) Vidpovidalnist derzhavy za znyshchennia tsyvilnoho povitrianoho sudna v rezultati zastosuvannia zbroi. Evropsky politicky a pravni diskurz-European political and legal discourse, vol.5, issue 2, 25-36. URL:http://nbuv.gov.ua/UJRN/evrpol_2018_5_2_5. [in Ukrainian].

10. Malovatskyi, O. V. Mizhnarodno-pravova vidpovidalnist derzhavy za znyshchennia tsyvilnoho povitrianoho sudna. Extended abstract of candidate's thesis. Instytut zakonodavstva Verxovnoyi Rady Ukrayiny. [in Ukrainian].

11. Hryhorov, O. M. (2020) Mizhnarodno-pravovi zasady rehuliuvannia vidnosyn u sferi tsyvilnoi aviatsii: stanovlennia ta rozvytok: monohrafiia. Kuiv. [in Ukrainian].

12. Rezoliutsiia HA OON № 56/589 (2001); Rezoliutsiia 71/133 HA OON (2016); rezoliutsiia 2166 RB OON (2014) N. p. URL:www.un.org. [in English].

13. Uhoda mizh Ukrainoiu ta Korolivstvom Niderlandiv pro mizhnarodne pravove spivrobitnytstvo shchodo zlochyniv, poviazanykh zi zbyttiam litaka reisu MN17 Malaiziiskykh avialinii 17 lypnia 2014 r. Uhodu ratyfikovano iz zaiavamy Zakonom № 2506-VIII vid 12.07.2018. (2018) URL:https://zakon.rada.gov.ua/laws/show/528_002-17\#Text. [in Ukrainian].

14. Povitrianyi kodeks Ukrainy/ redaktsiia vid 07.08.2020. (2020) URL:https:// zakon.rada.gov.ua/laws/show/3393-17\#Text. [in Ukrainian].

15. Pro zatverdzhennia Polozhennia pro vykorystannia povitrianoho prostoru Ukrainy: postanova KMU vid 6 hrudnia 2017 r. № 954. (2017) URL:https://zakon.rada. gov.ua/laws/ show/954-2017-\%D0\%BF\#Text. [in Ukrainian].

16. Kodeks Ukrainy pro administratyvni pravoporushennia. N. d. N. p. URL: https:// zakon.rada.gov.ua/laws/show/80731-10\#Text. [in Ukrainian].

17. Chykazka konventsiia pro mizhnarodnu tsyvilnu aviatsiiu 1944 r. (1944) N. p. URL:https://zakon.rada.gov.ua; ICAO (EUR/NAT). International Civil Aviation Organization. URL:https:// www.icao.int/. [in English].

18. Convenio iberoamericano de navegación aérea. (1929) Poder Ejecutivo Federal. Estados Unidos Mexicanos. México. [in English].

19. Monrealska konventsiia pro unifikatsiiu deiakykh pravyl mizhnarodnykh povitrianykh perevezen 1999r. (1999), Konventsiia pro shkodu zavdanu inozemnym povitrianym sudnom tretim osobam na poverkhni 1952 r. (1952), Monrealska konventsiia pro borotbu z nezakonnymy aktamy, spriamovanymy proty bezpeky tsyvilnoi aviatsii 1971 r. (1971) URL:https://zakon.rada.gov.ua/. [in English].

20. Voitsikhovskyi, A. V. (2020) Mizhnarodne pravo: pidruchnyk. Kharkiv. [in Ukrainian].

21. Kaminska, N., Siokh, K., Demidenko, V. (2018). Trends in the Development of International Legal Personality and Subjects of International Law: Theoretical Analysis. OPCION. Universidad del Zulia, vol. 34, № 87-2, 507-520. [in English].

22. Bychkov, A. S. (2010) Administratyvna vidpovidalnist za porushennia pravyl bezpeky polotiv. Extended abstract of candidate's thesis. Kyiv. [in Ukrainian].

23. Razvadovskyi, V. Y. (2004) Mistse zakonodavstva, yake mistyt normy administratyvnoho prava, u transportnomu zakonodavstvi. Nashe pravo - Our right, 2, 38-45. [in Ukrainian].

24. Nesterovych, V. F. (2010) Mizhnarodno-pravove zakriplennia instytutu lobiiuvannia na prykladi Rady Yevropy ta modelnoho zakonotvorennia SND. Mizhnarodnyi naukooyi zhurnal "Vlada. Liudyna. Zakon"- International scientific journal "Power. Man. Law", 9, 33-41. [in Ukrainian]. 
25. Nesterovych, V.F. (2011)Konstytutsiino-pravovi zasady zdiisnennia vplyvu hromadskostina pryiniattia normatyvno-pravovykh aktiv v Ukraini. Biuleten Ministerstva yustytsii Ukrainy - Bulletin of the Ministry of Justice of Ukraine, 3, 32-41. [in Ukrainian].

26. Pasichuk, A. M. Adaptatsiianatsionalnoho aviatsiinoho zakonodavstva donorm ta pryntsypiv YeS. N. d. URL:https://nau.edu.ua/site/variables/docs/docsmenu/stud nauka/polit2013/tezy/522$561 \% 20 \% \mathrm{D} 0 \% \mathrm{BF} \% \mathrm{D} 1 \% 80 \% \mathrm{D} 0 \% \mathrm{~B} 0 \% \mathrm{D} 0 \% \mathrm{~B} 2 \% \mathrm{D} 0 \% \mathrm{BE}$. pdf. [in Ukrainian].

Стаття надіӥщла до редколегії 02.09.2020

Каминская Н. В.,

доктор юридических наук, профессор, профессор кафедры конституционного права и прав человека Национальной академии внутренних дел (г. Киев, Украина)

Акимов Н. А.,

кандидат юридических наук, доцент, доцент кафедры уголовного права

Национальной академии внутренних дел

(г. Киев, Украина)

\section{ОТВЕТСТВЕННОСТЬ ГОСУДАРСТВА ЗА УНИЧТОЖЕНИЕ ГРАЖДАНСКИХ ВОЗДУШНЫХ СУДОВ: ОСОБЕННОСТИ МЕЖДУНАРОДНО-ПРАВОВОГО И НАЦИОНАЛЬНОГО РЕГУЛИРОВАНИЯ}

В статье проведен анализ существующих международно-правовых и некоторых национальных источников как оснований наступления ответственностиза уничтожение гражданских воздушных судов наряду с другими неправомерными действиями в сфере международной гражданской авиации. Это обусловило изучение состояния международноправового и национального правового регулирования института ответственности.

Раскрыты особенности привлечения к ответственности государств как основных субъектов воздушного права, в отличие от физических и юридических лищ, международных организаций, других субъектов.

Хотя уничтожения и повреждения гражданского воздушного судна в полете противоречит принщипу безопасности гражданской авиации, закрепленному Чикагской конвенщией, и требованиям воздерживаться от применения оружия гражданских воздушных судов в полете, установленных Протоколом об изменениях Конвенции о международной гражданской авиации 1984 (Монреальский протокол), такие акты приобрели угрожающее распространение.

В целом международно-правовая ответственность государства за уничтожение гражданского воздушного судна и, в частности, порядок принудительного исполнения ею соответствующих обязательств в части возмещения убытков остается недостаточно урегулированным, основывается в основном на обычных положениях, и нуждается в дальнейшей международной и национальной правотворческой деятельности.

Ключевые слова: ответственность государства, международно-правовое регулирование, законодательство, уничтожение гражданских воздушных судов, неприменение оружия, гражданская авиация, международные организации. 


\section{Kaminska N., \\ Doctor of Law, Professor, \\ Professor of the Department of Constitutional Law and Human Rights National Academy of Internal Affairs \\ (Kyiv, Ukraine) \\ Akimov M., \\ Candidate of Law, Associate Professor, Associate Professor of Criminal Law National Academy of Internal Affairs \\ (Kyiv, Ukraine)}

\section{STATE RESPONSIBILITY FOR THE DESTRUCTION OF CIVIL AIRCRAFT: FEATURES OF INTERNATIONAL LAW AND NATIONAL REGULATION}

The article analyzes the existing international legal and some national sources as grounds for the state's liability for the destruction of civil aircraft, along with other illegal acts in the field of international civil aviation. This led to the study of the state of international law and national legal regulation of the institution of state responsibility. The peculiarities of bringing states to justice as the main subjects of air law, in contrast to individuals and legal entities, international organizations, and other subjects, are revealed.

Although the destruction and damage of civil aircraft in flight is contrary to the principle of civil aviation safety enshrined in the Chicago Convention and the requirements to refrain from using weapons to civil aircraft in flight established by the Protocol Amending the 1984 Convention on International Civil Aviation (Montreal Act), have become threateningly widespread. In general, the international legal responsibility of the state for the destruction of a civil aircraft and, in particular, the procedure for enforcing its obligations in terms of compensation remains insufficiently regulated, based largely on customary provisions, and therefore require further international and national lawmaking.

It is concluded that the international legal responsibility of the state for the destruction of a civil aircraft and, in particular, the procedure for enforcement of its obligations in terms of compensation remain insufficiently regulated, based largely on customary provisions, and therefore require further international and national lawmaking. Attention should be paid to the issues of increasing the responsibility of states and other entities, improving the security system of civil aviation not only after the emergence of potential threats and terrible consequences, but also to prevent them, and in case of their occurrence - prompt investigation of such incidents, prosecution. and compensation for damages.

Keywords: state responsibility, international legal regulation, legislation, destruction of civil aircraft, non-use of weapons, civil aviation, international organizations. 